entreCaminos, v.1, jul-dez 2015

Yoanky Cordero Gómez

\title{
O SOM DO CORPO
}

I

Onde escondi selva e terra

o verde do amor ficou nú.

Longe do tremor da guerra,

a nova porta virou azul.

A luz avermelha, erra

a cor das palavras, bambú

e o vaivém do céu na serra

pinta o arco-íris de urubú.

Assovio minha vitoria

pois teus olhos são a gloria

majestosa dos meus corpos

Fala-me, se silencias

Grita-me, se vivencias:

roces, peles, anticorpos.

II

Muérome de uma morte [alheia]

convocada,

em agudos levantados

Muérome da tesão do [rencor] 
entreCaminos, v.1, jul-dez 2015

de corpos arrepiados

do que não me pertence

do furtado

da réplica de mis [sueños]

É uma morte que late três veces longe

y que [vacila...]

Muérome dos cantos,

das brújulas que trotan o [corpo]

Muérome das tuas letras na [minhas mãos],

de tus palabras tremendo na minha [boca].

È uma morte:

terçã- rosa

quinta- céu

sexta- cisne

[Morro-me!] 